\title{
Trypanorhynch Cestodes of Commercial Fishes from Northeast Brazilian Coastal Waters
}

\author{
Harry W Palm
}

Marine Pathology Group, Department of Fisheries Biology, Institut für Meereskunde an der Universität Kiel, Düsternbrooker Weg 20, D-24105 Kiel, Germany

\begin{abstract}
A large scale investigation on trypanorhynch cestode infestation of tropical marine fishes was carried out along the Northeast Brazilian coast in the summer of 1991 and 1993. A total of 798 fish specimens belonging to 57 species and 30 families were examined. Metacestodes of 11 different trypanorhynchs were found: Callitetrarhynchus gracilis, Dasyrhynchus giganteus, Grillotia sp., Nybelinia edwinlintoni, N. indica, N. senegalensis, Nybelinia c.f. lingualis, Otobothrium cysticum, Pseudolacistorhynchus noodti, Pseudotobothrium dipsacum and Pterobothrium kingstoni. Scanning electron microscopy was used to clarify details of the tentacular armature of some species. Rose-thorn shaped hooklets, regularly arranged like microtriches, are described from the bothridial surface of N. edwinlintoni. Of the 57 fish species, 15 harboured trypanorhynch cestodes. Of these the mullid Pseudupeneus maculatus was the most heavily infested fish species, harbouring 5 different trypanorhynch species. P. noodti in P. maculatus had the highest prevalence $(87 \%)$ and intensity (maximum $=63)$ of infestation. C. gracilis was the parasite with the lowest host-specificity. It could be isolated from 10 fish species. The cestode fauna of the Northeast Brazilian coast appears to be similar to that of the West African coast. Five of the trypanorhynch cestodes found during this study are common to both localities. The two single cases of intra musculature infestation in Citharichthys spilopterus and Haemulon aurolineatum by trypanorhynch cestodes indicate that marketability of the investigated commercially exploited fish species is inconse-
\end{abstract} quential.

Key words: Brazil - parasites - cestodes - Trypanorhyncha - distribution - commercial fishes - food hygiene

Trypanorhynch cestodes mature in elasmobranchs and often use teleost fishes as intermediate or transport hosts. Though accidental human infections are scarce (Bates 1990), worms in the fish flesh or body cavity reduce the fish market value by making them unappealing to consumers (Deardorff et al. 1984). It was necessary to develop new fish processing methods before marketing the walleye pollock Theragra chalcogramma, which is heavily infested with metacestodes of Nybelinia surmenicola (Arthur et al. 1982). The flesh of Brama rai and Thyrsites atun could only be used as fish meal or pet food due to heavy infestations with Gymnorhynchus gigas and G. thyrsitae (Mehl 1970, Seyda 1976).

In temperate waters the parasite fauna of commercially exploited fish species is fairly well known as a result of the highly developed large-scale fishing industry (Palm et al. 1994). In contrast, fishing activities of many tropical countries are restricted

Financial support was provided within the framework of the German/Brazilian cooperation and the German Research Council (DFG).

Fax: +49-431-597.3994. E-mail: hpalm@ifm.uni-kiel.de Received 9 April 1996

Accepted 4 September 1996 to a small-scale inshore subsistence artisanal fishery, which is conducted from small coastal villages. In the tropics most of the catch is consumed directly by the fishermen and their families, and the remainder is sold at local markets. Although fish is of primary importance in such communities, the local distribution of the fishery products often produces only minor official interest and thus minor research activities in the field of applied fisheries research. Consequently, relatively few investigations have been carried out on parasitism of tropical marine fish. The growing importance of fish as a protein resource, and the interest in exporting fishery products to markets with high quality standards, requires knowledge of fish health in exploited stocks.

Information about trypanorhynch cestode infestation along the tropical coast of Brazil are restricted to the records of Santos and Zogby (1971), Klein (1975), Rego (1977, 1987) and Palm (1995). Further investigations have been carried out at the subtropical Southwest Brazilian coast (Mendes 1944, Rego et al. 1974, Pissaia Saciloto 1980, Pereira et al. 1982, Carvajal \& Rego 1983, 1985, São Clemente 1982, 1986a,b, São Clemente \& Gomes 1989a,b, 1992, São Clemente et al. 1991). However, all are observations on only one or a few parasite species and Palm (1995) gave no data concerning parasite 
abundance and prevalence of infestation.

Recently, a survey of the parasite fauna of fish from a Nigerian estuary, a tropical area similar to the Northeast Brazilian coast, was carried out by Palm et al. (1994). The authors studied 45 fish species and isolated metacestodes of 9 different trypanorhynchs; 2 of them infesting the fish flesh. The aim of the present paper is to present infestation rates of trypanorhynch cestodes in the musculature and viscera of commercially exploited fish from a tropical Brazilian locality. The results provide new information on the distribution patterns of the species and their meaning for commercial fisheries.

\section{MATERIALS AND METHODS}

During July-August 1991 and August-September 1993, the flesh of a total of 798 fishes belonging to 57 species and 30 families were examined for cestode infestation. Of that total 549 specimens were examined for trypanorhynch cestodes in the body cavity and the viscera without gut content. Fish were obtained from local markets or directly from fishermen on Itamaracá Island and in Itapissuma, Northeast Brazil (Fig. 1). A few fish were obtained from Ponta de Pedras, a small fishing village about $30 \mathrm{~km}$ north of Itamaracá. Though the exact catch location of the fish could not be determined, most fish came from the St. Cruz Canal and a coral reef east of the island.

All fish sampled were purchased as fresh or frozen specimens. In the laboratory they were measured, filleted and the skin removed. The fillets were placed on a candling table over a fluorescent light source to detect any parasites. Thick fillets were sliced lengthwise and pressed to a thickness of approximately 3-5 $\mathrm{mm}$ between two acrylic glass plates. The body cavity and the viscera were examined with the help of a stereoscopic dissecting microscope with 6x magnification.

The isolated cestodes were washed in saline solution and fixed in $10 \%$ buffered formalin. Specimens were stained in Acetic-Carmine, dehydrated and mounted in balsam. To study the tentacular armature of some of the species with scanning electron microscopy (SEM) techniques, specimens were fixed in $2.5 \%$ glutaraldehyde, dehydrated in an alcohol series, critical point dried with $\mathrm{CO}_{2}$ and mounted with conducting tubs onto stubs. These stubs were sputter-coated with gold-palladium in an argon atmosphere and examined with a Zeiss DSM SEM at 10 to $15 \mathrm{kV}$.

In the taxonomic sections of this communication, the following abbreviations are used for the different body parts of the metacestodes: Scolex length (SL), Scolex width at level of pars bothridialis $(\mathrm{SW})$, pars bothridialis (pbo), pars vaginalis ( $p v)$, pars bulbosa (pb), pars postbulbosa (ppb), appen-

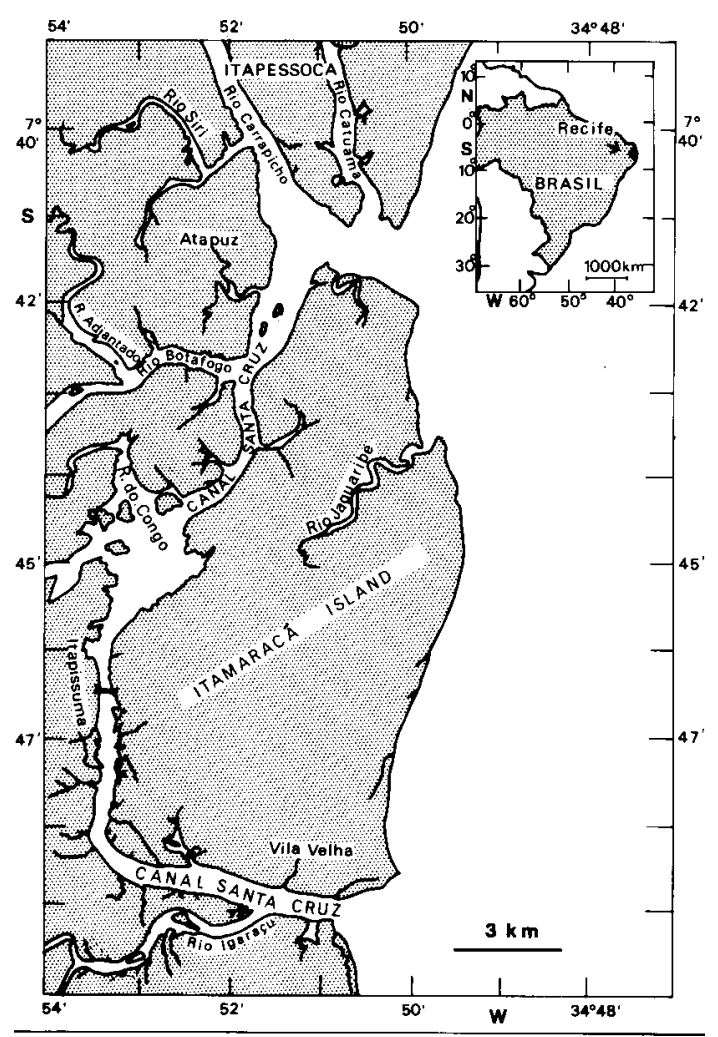

Fig. 1: map showing area of investigation.

dix (app) and velum (vel). All measurements are given in micrometers unless otherwise indicated. The range is given in parentheses. If no measurements are given they were published by Palm (1995). The classification as well as orientation of tentacle surfaces follows that of Palm (1995).

\section{RESULTS}

Eleven species of trypanorhynch cestodes were isolated from 15 fish species of the 57 fish species investigated (Table). All parasite species detected represent the first locality records in the investigated area. Most also represent the first host records, the exceptions being Callitetrarhynchus gracilis in Caranx crysos, Scomberomorus maculatus and Selene vomer, Dasyrhynchus giganteus in Caranx hippos and Otobothrium cysticum in Sphyraena guachancho. The majority of the trypanorhynchs occurred in the body cavity and mesenteries. The fish flesh was infested in only two cases, once with C. gracilis in Haemulon aurolineatum and once with Pterobothrium kingstoni in Citharichthys spilopterus. Remarks on the individual species isolated, particularly on their taxonomy, zoogeography and occurrence in the fish flesh, are presented below, according to parasite species. 
TABLE

Occurrence of trypanorhynch cestodes in commercial fish species from the Northeast Brazilian coast

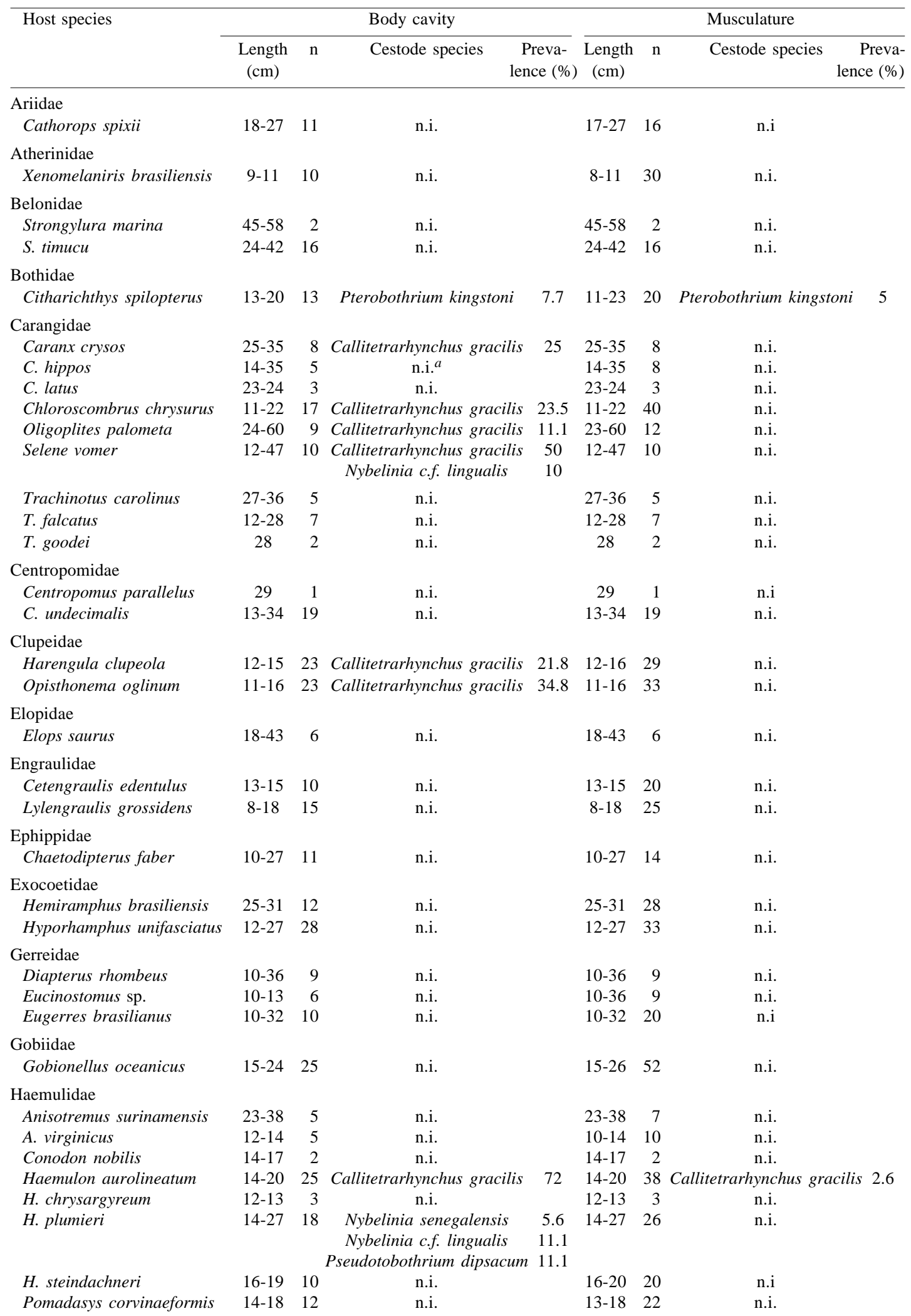




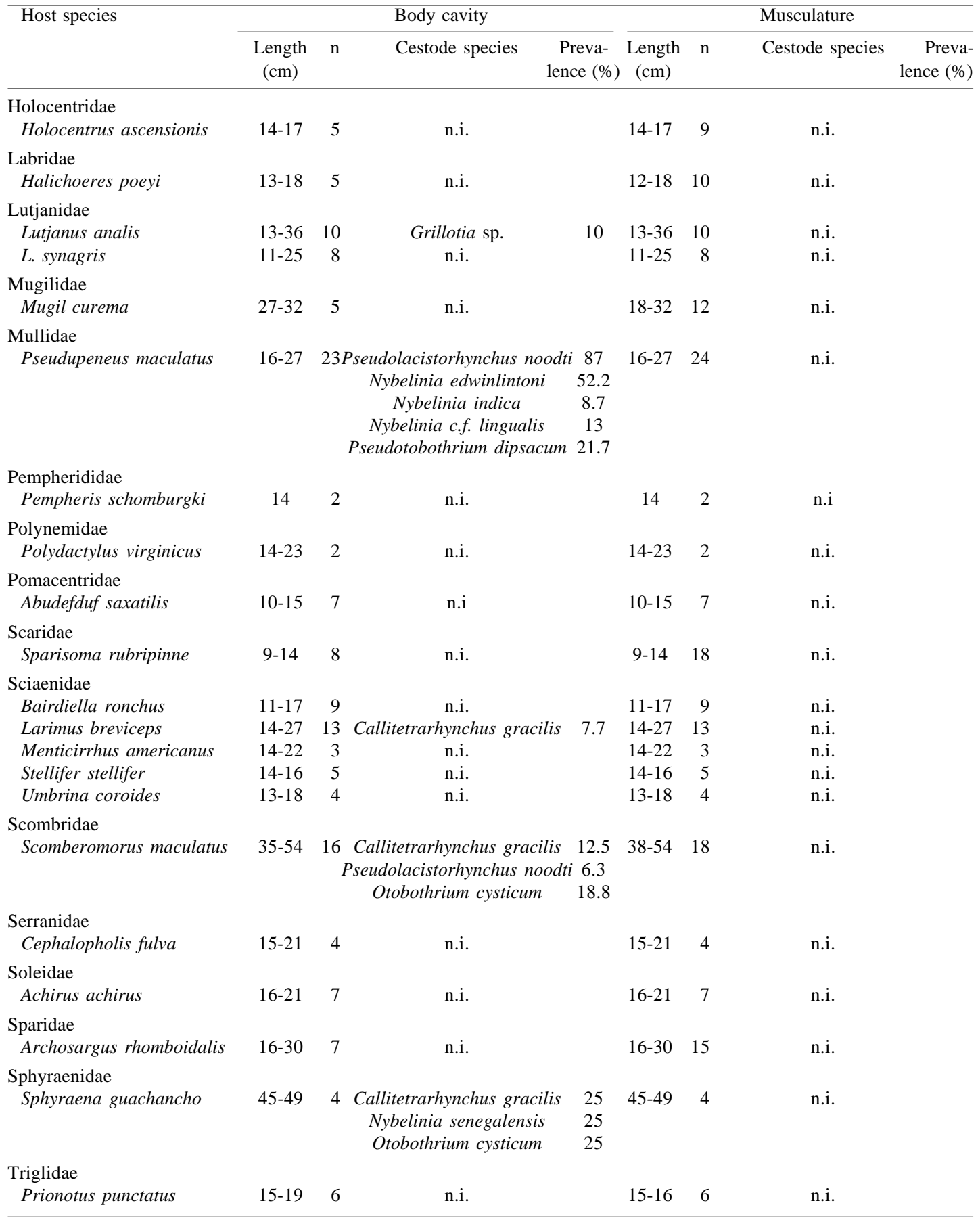

n.i.: not infested; a: Dasyrhynchus giganteus present in the brain of one extra fish.

Superfamily: Tentacularioidea Poche, 1926 Family: Tentaculariidae Poche, 1926 Nybelinia edwinlintoni Dollfus, 1960

N. edwinlintoni was highly host specific and occurred only in the mullid Pseudupeneus maculatus. The postlarvae were found free in the body cavity or encapsulated in the mesenteries and in the stomach wall. The prevalence of infestation was high with $52 \%$ and a maximum intensity of 8 . The morphological characters correspond to those given by Dollfus (1960). In Fig. 2a-c the uniform and subequal hooks of the proboscis and hooklets 
as well as spines on the distal surfaces of bothridia are shown with SEM.

The present finding extends the distribution of the species from the West African coast to the Southwest Atlantic. Postlarvae of Nybelinia species are often found in the stomach wall or the body cavity of various hosts. Though some congeners like $N$. erythreae, $N$. indica and $N$. surmenicola are known to invade the fish flesh to the extend of affecting market value (Dollfus 1960, Arthur et al. 1982, Chandra 1986) invasion of the musculature has not been previously reported for $N$. edwinlintoni.

\section{Nybelinia indica Chandra, 1986}

Two postlarvae of $N$. indica were found free in the body cavity of two $P$. maculatus. The small scolex of one of the specimens measured: $\mathrm{SL}=640$, $\mathrm{SW}=540, p b o=360, p v=200, p b=100, a p p=320$. The hooks on the basal and metabasal part of the tentacle appear different. Basal, small and solid hooklets (5) increasing in size and metabasal, large and more slender, spiniform hooks (up to 24) were evident. Though having only half of the scolex length described for $N$. indica (Chandra 1986), the present specimen is nearly identical in the size of hooklets (6-23 for N. indica) as well as in the ratios of SL to $\mathrm{SW}, \mathrm{SL}$ to $p b o$ and SL to the bulb length.

This is the first record for $N$. indica from the Atlantic Ocean, indicating that this species might have a world wide distribution. This species is known to infest the musculature of various fish hosts (Chandra 1986). Though it could not be demonstrated during this study, the potential of N. indica to invade the fish flesh should be noted.

\section{Nybelinia senegalensis Dollfus, 1960}

Two specimens of $N$. senegalensis were isolated from the stomach wall of a $S$. guachancho and the body cavity of a $H$. plumieri. The scolex measurements were as follows: $\mathrm{SL}=1696$ (1430), $\mathrm{SW}=780$ (702), $p b o=793$ (676), $p v=832$ (650), $a p p=377$ (299), vel $=247$ (208). The bulbs were 379 (371) long to 106 (90) wide. The hooklets of the homeoacanthous armature were dissimilar in size, 5.9 to 6.5 on the external and 7.2 to 8.5 on the internal surface. Dollfus (1960) recorded three species with similar morphological characters like the present specimens. Of these, $N$. punctatissima has been reported from the same fish host ( $S$. guachancho) and with an equal bulb ratio but with a smaller size and bigger hooklets. The measurements given for N. estigmena correspond in SL, length of $p b o$ and app and a similar bulb range to the specimen isolated from $S$. guachancho. However, the bulb ratio of the second specimen, similar ratios of SL to SW, SL to pbo, SL to vel and a similar hook size of both specimens indicate that the present specimens belong to $N$. senegalensis (Values of hook size for $N$. senegalensis: 6.5-7.5 (external surface) to 8-8.5 (internal surface).

The present record extends the known distribution for the species to the tropical western part of the Atlantic. Like N. edwinlintoni this species is not known to infest the musculature of its fish host. Nybelinia c.f. lingualis (Cuvier, 1817)

Postlarvae of this species were isolated from the body cavity of $H$. plumieri, $P$. maculatus and $S$. vomer with a prevalence of 11,13 and $10 \%$. The following measurements of a single specimen were taken: $\mathrm{SL}=1216, \mathrm{SW}=1040, p b o=702, p v=429$, $a p p=455$, vel $=455$. The bulbs were 289 long to 134 wide. The tentacular armature consisted of solid hooks (15-18 long and 11-15 implantation base in the metabasal region of the tentacle), having the same size on the different tentacle surfaces. The short tentacles appeared wider in the basal part, leading to a slender apical part. The hooklets towards the end of the proboscis show minor differences to those of the basal and metabasal part. The armature is similar as well as bulb length and bulb ratio to those described for N. lingualis (Dollfus 1942, figs 8891). However, though having comparable morphometrical data (SL to SW, SL to $p b o$, SL to $p b$ ) the sizes of hooklets differ from specimens of $N$. lingualis redescribed by São Clemente and Gomes (1989b) from South Brazilian coastal waters.

Superfamily: Tentacularioidea Poche, 1926

Family: Lacistorhynchidae Guiart, 1927

Callitetrarhynchus gracilis (Rudolphi, 1819)

The cosmopolitan species $C$. gracilis was the trypanorhynch cestode with the widest host range (low host specificity). It was detected in 10 of the fish species examined with the highest prevalence of infestation of $72 \%$ (Table). The morphological characteristics of the scolices correspond to the descriptions of Dollfus (1942) and Carvajal and Rego (1985). Fig. 2d shows the hooklet arrangement of the metabasal tentacular armature. The species was found in two different size groups, small scolices $(1.5-2.1 \mathrm{~mm})$ in blastocysts with $1.5-3 \mathrm{~mm}$ total length (C. chrysos, Chloroscombrus chrysurus, $H$. aurolineatum, Harengula clupeola, Opisthonema oglinum) and big scolices $(0.6-1 \mathrm{~cm})$ in blastocysts with $0.8-1.3 \mathrm{~mm}$ total length (Larimus breviceps, Oligoplites palometa, S. maculatus, S. vomer, $S$. guachancho). A four stage life cycle including two teleosts as second and third intermediate hosts was recently proposed by Palm et al. (1994). In one $H$. aurolineatum three small, black coloured blastocysts of $C$. gracilis were found in the musculature.

This is the first record of this species from the fish flesh and must be seen as a case of an acciden- 

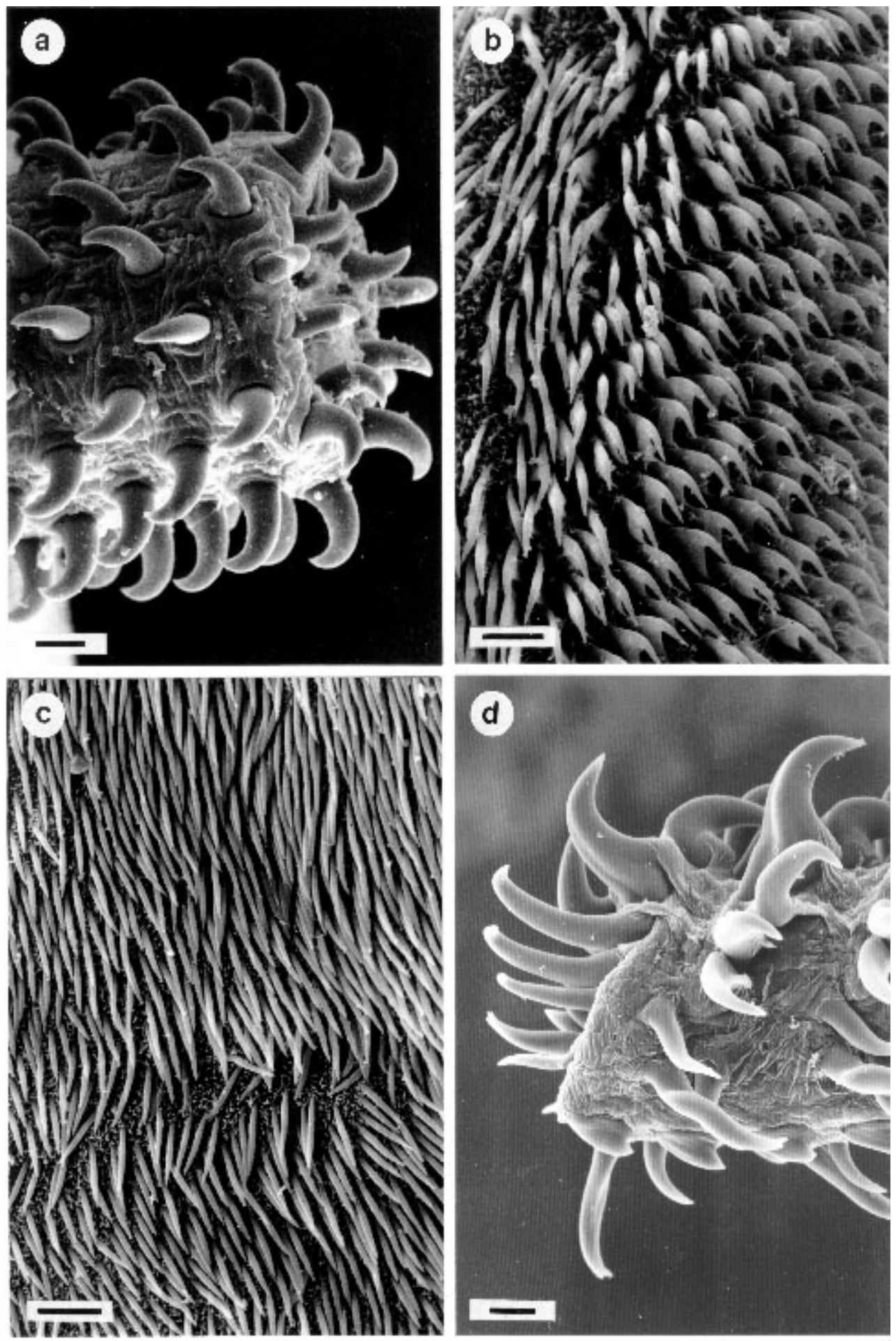

Fig. 2: Nybelinia edwinlintoni and Callitetrarhynchus gracilis. a: homeoacanthous armature of $N$. edwinlintoni, metabasal (scale bar $=10 \mu \mathrm{m})$. b: small hooklets on the distal surfaces of bothridia of $N$. edwinlintoni $($ scale bar $=5 \mu \mathrm{m})$. c: spiniform hooklets interspersed among microtriches on the distal surfaces of bothridia of $N$. edwinlintoni (scale bar $=5 \mu \mathrm{m}$ ). $\mathrm{d}$ : poeciloacanthous armature of $C$. gracilis (scale bar $=5 \mu \mathrm{m}$ ). 
tal infestation, the normal sites of infestation for the cosmopolitan $C$. gracilis are the body cavity and the mesenteries. The very small size of the blastocysts and the low infestation rate of the flesh produce no further problems for human consumption.

\section{Dasyrhynchus giganteus (Diesing, 1850)}

At 2 September 1993 approximately 300-400 Caranx hippos with total lengths of 50 to $60 \mathrm{~cm}$ were landed by artisanal fishermen at Itapissuma. From the brain of a single of these fish, three specimens of D. giganteus were isolated directly on the fish market. Five other specimens examined during the main investigation with a total size of 14$35 \mathrm{~cm}$ were not infested (Table). Beveridge and Campbell (1993) stated that it is not possible to separate $D$. giganteus from the related $D$. variouncinatus only on the basis of the hooklet arrangement. Examination of segment anatomy of adult worms is necessary to differentiate the species. However, currently all specimens found in the Atlantic Ocean with a hooklet arrangement typical for these two species are considered as belonging to D. giganteus (Beveridge \& Campbell 1993).

This species was originally described from Brazil and has a transoceanic distribution in the tropical part of the Atlantic. Though D. giganteus has not been reported from the musculature of its hosts, some congeners are known to infest the fish flesh with their large blastocysts (Reimer 1981, Deardorff et al. 1984).

\section{Pseudolacistorhynchus noodti Palm, 1995}

Metacestodes of $P$. noodti were found in the mesenteries of $P$. maculatus and $S$. maculatus with a prevalence of infestation of 87 and $6 \%$. In most $P$. maculatus examined conglomerations containing up to 20 blastocysts were detected at the end of the body cavity near the anus. The highest intensity of infestation was 63. Linton (1909 figs 7073, 1924 figs 108-109) described specimens of $P$. noodti from Dry Tortugas and Woods Hole. He could not identify the species and therefore he named his specimens Rhynchobothrium sp.

Thus, with this finding of Pseudo-lacistorhynchus noodti, its distribution is extended from the Northwest Atlantic to the Northeast Brazilian coast. Muscular infestation was not found during this study.

\section{Grillotia sp.}

A single specimen of an unidentified Grillotia was isolated from the body cavity of a Lutjanus analis. The large sized blastocyst $(1.8 \mathrm{~cm}$ total length) was of white colour and had one enlarged end, including the scolex. The following measurements were taken: $\mathrm{SL}=3560, p b o=585, p v=2834$, $p b=472, p p b=254$. Though the tentacles were invaginated, a heteroacanthous atypica armature with
5 to 6 different hooks arranged in principal rows on the bothridial and antibothridial surfaces were visible inside of straight tentacle sheaths. A specific basal armature could not be detected. The acraspedote scolex carrying two bothridia as well as unwinded tentacle sheaths lead to the classification of the present specimen as belonging to the genus Grillotia.

Superfamily: Tentacularioidea Poche, 1926 Family: Gymnorhynchidae Dollfus, 1935

Pterobothrium kingstoni Campbell \& Beveridge, 1996

Six metacestodes of $P$. kingstoni were found in the liver and the musculature of a C. spilopterus. The scolices were isolated out of the enlarged end of 1 to $2 \mathrm{~cm}$ long blastocysts. Details of the tentacular armature are shown on Fig. 3a-c. The morphological characters correspond to those given by Campbell and Beveridge (1996).

The present finding extends the distribution of P. kingstoni from the Northeast American (Virginia, USA) to the East Brazilian coast. Beside $C$. gracilis, $P$. kingstoni was the only species found during this study having a flesh invading potential. Several congeners like $P$. crassicolle, $P$. heteracanthum and $P$. lintoni are known to invade the fish flesh (Overstreet 1977, São Clemente et al. 1991). However, though in this case the affected fish might not be useful for human consumption due to the large sized blastocysts, a low infestation rate indicates no serious marketing problems due to this parasite.

Superfamily: Otobothrioidea Dollfus, 1942

Family: Pseudotobothriidae Ward, 1954

Pseudotobothrium dipsacum (Linton, 1897)

Specimens of $P$. dipsacum were isolated from H. plumieri and P. maculatus at a prevalence of 11 and $22 \%$. The scolices were situated inside large blastocysts in the mesenteries of the fish hosts, the preferred infestation site of the species. They were identified according to Dollfus (1942). Details of the unique arrangement of the hooklets on the tentacles were recently documented by Palm et al. (1994). The three-fingered microtriches on the inner side of the bothridia are shown on Fig. 3d-e.

This first finding of the species in the tropical part of the Southwest Atlantic supports a world wide distribution pattern for Pseudotobothrium dipsacum in tropical and subtropical waters. No musculature infestation could be detected during this or a previous study (Palm et al. 1994).

Superfamily: Otobothrioidea Dollfus, 1942 Family: Otobothriidae Dollfus, 1942

Otobothrium cysticum (Mayer, 1842)

Blastocysts of this small trypanorhynch cestode were found encapsulated in the mesenteries of 

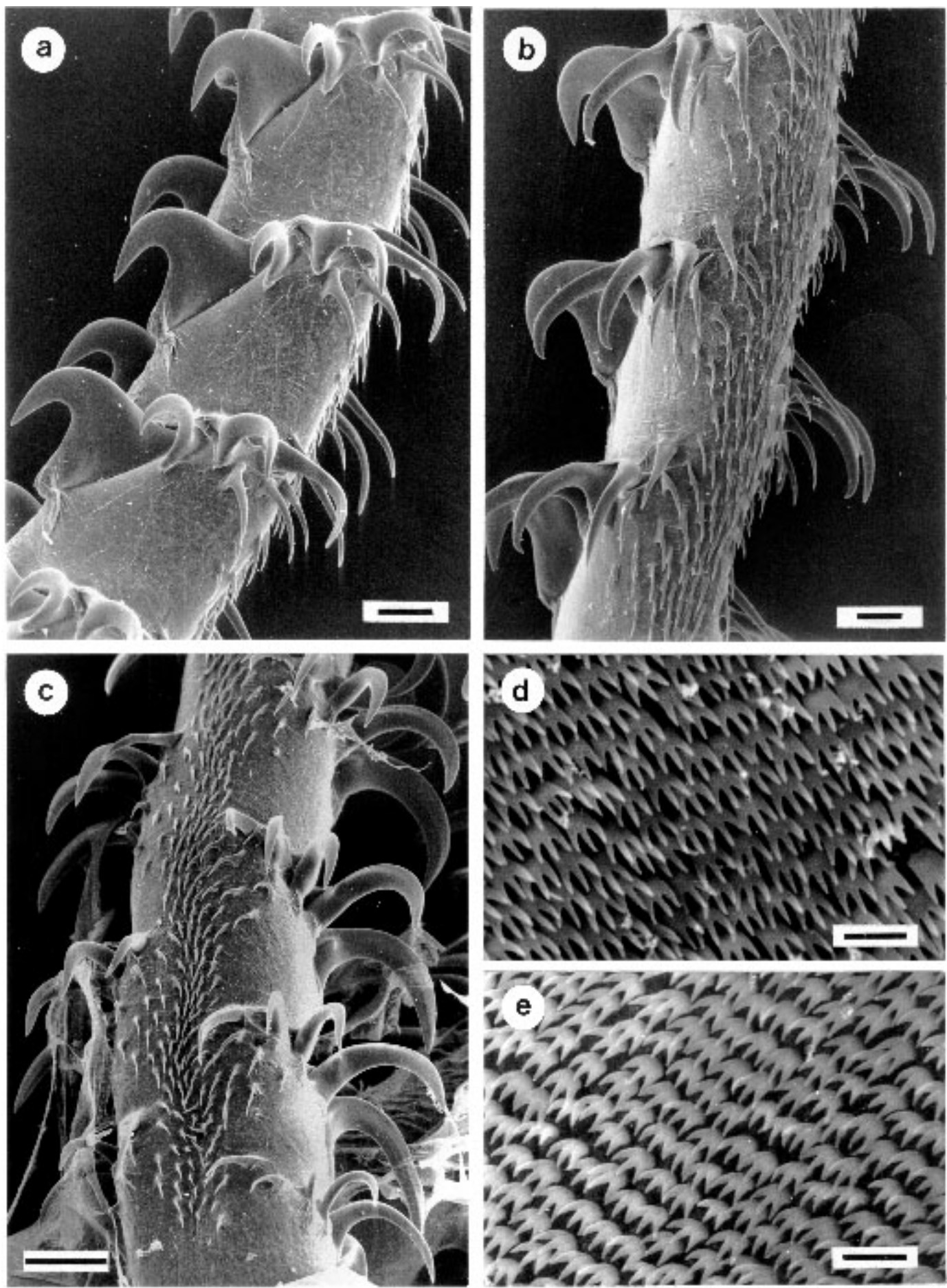

Fig. 3: Pterobothrium kingstoni and Pseudotobothrium dipsacum. a: heteroacanthous armature of P. kingstoni, bothridial surface, metabasal (scale bar $=25 \mu \mathrm{m})$. b: $P$. kingstoni, external surface, metabasal (scale bar $=25 \mu \mathrm{m})$. c: $P$. kingstoni, external surface, basal (scale bar $=50 \mu \mathrm{m})$. d: and e: microtriches on the distal surfaces of bothridia of $P$. dipsacum $($ scale bar $=2 \mu \mathrm{m})$. 
Scomberomorus maculatus and S. guachancho. The prevalence of infestation was 19 and $25 \%$. Morphological characteristics correspond with those given by Dollfus (1942).

The present record greatly extends the distribution area of the species from the West African coast to the Southwest Atlantic. Though flesh infestations have not been reported for $O$. cysticum during a recent study (Obiekezie et al. 1992, Palm et al. 1994), O. crenacolle, which was seen as a junior synomym for $O$. cysticum by Palm (1995), causes marketing problems for the butter fish Prionotus triacanthus at the Northeast American coast (Linton 1908). Furthermore, several species of the genus Otobothrium like $O$. arii, $O$. insigne and $O$. penetrans are known to infest the musculature of various fish hosts (Bilquees \& Shaukat 1976, Hildreth \& Lumsden 1985, Reimer 1989, Palm et al. 1993, Petersen et al. 1993). Thus a flesh invading potential of the species should not be excluded.

\section{Other cestodes}

Additional to 11 trypanorhynch cestode species, metacestodes belonging to an unidentified species of the genus Rhinebothrium Linton, 1890 (Tetraphyllidea) were found in the body cavity of Gobionellus oceanicus. The prevalence of infestation was $68 \%$ with a maximum intensity of 34 . A single specimen of Scolex pleuronectis (Tetraphyllidea) was found in the body cavity of a Hyporhamphus unifasciatus.

\section{DISCUSSION}

The present study is the first large-scale investigation on trypanorhynch cestodes of fishes from the tropical Southwest Atlantic Ocean. A total of 20 new host and 11 new locality records have been established. Trypanorhynchs were the predominant cestodes represented in the area. Only two tetraphyllid species were found in the fish examined. Related to the unavailability of suitable final hosts, no pseudophyllids including the zoonotic genera Diphyllobothrium and Diplogonoporus were found (Obiekezie et al. 1992, Palm et al. 1994).

The cestode fauna of the tropical Brazilian coastal zone is similar to that of the West African coast. Five of the trypanorhynchs detected during this study are common for both localities (Dollfus 1960, Palm et al. 1994). Considering the records of $N$. lingualis, N. rougetcampanae, Poecilancistrum caryophyllum and Tentacularia coryphaenae of the South Brazilian coast, 9 trypanorhynchs have been described from both, the Brazilian and the West African coast (Dollfus 1935, 1960, BaudinLaurencin 1971, Rego 1977, Pereira et al. 1982, São
Clemente \& Gomes 1989b, 1992, Palm et al. 1994). C. gracilis was the most common trypanorhynch occurring in 10 different host fish species. Palm et al. (1994) showed a wide host range for O. cysticum infesting 8 of 45 fish species of the West African coast. A total of 29 of 40 fish species in the Arabian Gulf as well as 6 of 10 sciaenids in the Gulf of Mexico were found to harbour plerocerci of Floriceps sp. and Poecilancistrum caryophyllum (Overstreet 1977, El-Naffar et al. 1992). In all cases, other trypanorhynchs isolated from the same samples had narrow host ranges occurring in only one or a few fish species. Similarly, Schramm (1991) reported the musculature infestation of 8 out of 10 different mullet species from the Southeast African coast with metacestodes of Grillotia perelica, while this species was highly host specific as a swim-bladder parasite of Caranx senegallus at the West African coast (Palm et al. 1994). In spite of a wide geographic distribution, it seems that metacestodes of several trypanorhynchs prefer special localities. Palm et al. (1994) proposed, that the first intermediate host is the most important link in the completion of the trypanorhynch life cycle. In the case of the cosmopolitan $C$. gracilis, the final hosts would enable a trans-Atlantic distribution of the parasite resulting in the possibility of a similar wide host range off the Northeast Brazilian coast and in the Gulf of Guinea. At both localities the fish fauna supplying the second intermediate hosts is similar. Thus, the very different fish infestation patterns found during this and the former investigation (Palm et al. 1994) lead to the assumption that access to suitable first intermediate hosts (different species of crustaceans) must be different in these two localities.

Overstreet $(1977,1978)$ demonstrated that the so-called spaghetti-worm Poecilancistrum caryophyllum parasitizing sciaenid fishes is one of the most common trypanorhynchs of the northern Gulf of Mexico. The prevalence of infestation in the spotted seatrout Cynoscion nebulosus reached up to $49 \%$. The same parasite has also been recorded infesting Micropogonias furnieri from the South Brazilian coast (Pereira et al. 1982, São Clemente 1982, 1986a,b). Pereira (1992) showed that the prevalence of infestation increased along the Southern Brazilian coast from the litoral of Rio de Janeiro to Rio Grande do Sul from 0.9 to $9.83 \%$. In the tropical South Atlantic, however, only a single specimen of $P$. senegalensis has been found to be infested with two plerocerci of $P$. caryophyllum during this and a former investigation at the Nigerian coast (Palm et al. 1994). It is suggested that the distribution of $P$. caryophyllum, one of the most important flesh parasites in the 
order Trypanorhyncha, in the Atlantic has a limitation to the subtropical regions lying between 20 and $30^{\circ}$ North and South.

Parts of the scolex and distal bothridial surfaces of $N$. edwinlintoni were found to be covered with regularly arranged small hooklets. Observations on living specimens of tentaculariid trypanorhynchs with the ability to penetrate host tissue very quickly lead to the assumption that $N$. edwinlintoni uses these small hooklets for a special kind of movement. During the process of contracting and relaxing the scolex and simultaneously protruding the proboscis, the small hooklets may help to anchor the body in its position before the scolex pushes itself more forward throughout the host tissue. This would explain the arrangement of the hooklets with apices pointed towards the posterior part of the scolex.

Musculature infestation of commercial inshore fishes of the Northeast Brazilian coast by trypanorhynch metacestodes is rare. The flesh of only one Citharichthys spilopterus and one $H$. aurolineatum was found to be infested with specimens of $P$. lintoni and $C$. gracilis. In contrast to very small sized blastocysts of the latter species, $P$. kingstoni is easily visible and might exclude the fish specimens affected from human consumption. The two species were found in the flesh at very low prevalences, thus producing no concern for marketing or public health. Together with the results of the study carried out at the East Nigerian coast (Palm et al. 1994), it seems that in the tropical part of the Atlantic, no "real" problem caused by trypanorhynch metacestodes exists for the commercial inshore fisheries.

\section{ACKNOWLEDGEMENTS}

To Prof. Dr S Macedo (Universidade Federal de Pernambuco) and to the ZMT (Zentrum für Marine Tropenökologie, Bremen) for logistical support. ZCEF Lemos assisted with the processing of samples.

\section{REFERENCES}

Arthur JR, Margolis L, Whitaker DJ, McDonald TE 1982. A quantitative study of economically important parasites of walleye pollock (Theragra chalcogramma) from British Columbian waters and effects of post mortem handling on their abundance in the musculature. Can J Fish Aquat Sci 39: 710726.

Bates RM 1990. A checklist of the Trypanorhyncha (Platyhelminthes: Cestoda) of the world (19351985). National Museum of Wales, Cardiff, Zool Ser 1: 1-218.

Baudin-Laurencin F 1971. Crustacés et helminthes parasites de l'Albacore (Thunnus albacares) du Golfe de Guinée - Note préliminaire. Doc Scient Centre Rech Oceanogr Abidjan 2: 11-30.
Beveridge I, Campbell RA 1993. A revision of Dasyrhynchus Pintner (Cestoda: Trypanorhyncha), parasitic in elasmobranch and teleost fishes. System Parasitol 24: 129-157.

Bilquees F, Shaukat MN 1976. Otobothrium arii sp. n. in the fish Arius serratus (Day) from Karachi coast. Agricult Pak 27: 119-124.

Campbell RA, Beveridge I 1996. Revision of the family Pterobothriidae Pintner, 1931 (Cestoda: Trypanorhyncha). Invertebr Taxon 10: 617-662.

Carvajal J, Rego AA 1983. Progrillotia dollfusi sp. n. (Cestoda: Trypanorhyncha) parasito de pescada do litoral brasileiro. Mem Inst Oswaldo Cruz 78: 231234.

Carvajal J, Rego AA 1985. Critical studies on the genus Callitetrarhynchus (Cestoda: Trypanorhyncha) with recognition of Rhynchobothrium speciosum Linton, 1897 as a valid species of the genus Callitetrarhynchus. System Parasitol 7: 161-167.

Chandra KJ 1986. Nybelinia indica n. sp. (Cestoda: Trypanorhyncha) from teleost fishes of Waltair coast, Bay of Bengal. Riv Parassitol 3: 199-202.

Deardorff TL, Raybourne RB, Mattis TE 1984. Infections with trypanorhynch plerocerci (Cestoda) in Hawaiian fishes of commercial importance. Sea Grant Quart 6: 1-6.

Dollfus RP 1935. Sur quelques parasites de poissons recoltes a Castiglione (Algerie). Bull Trav 2: 199279.

Dollfus RP 1942. Études critiques sur les tétrarhynques du Museum de Paris. Arch Mus Hist nat Paris 19: $1-466$.

Dollfus RP 1960. Sur une collection de tétrarhynques homeacanthes de la famille des Tentaculariidae récoltées principalement dans la région de Dakar. Bull de l'Inst fr Afrique Noire, Ser A 22: 788-852.

El-Naffar MKI, Gobashy A, El-Etreby SG, Kardousha MM 1992. General survey of helminth parasite genera of Arabian Gulf Fishes (Coast of United Arab Emirates). Arab Gulf J Scient Res 10: 99-110.

Hildreth MB, Lumsden RD 1985. Description of Otobothrium insigne plerocercus (Cestoda: Trypanorhyncha) and its incidence in catfish from the Gulf of Louisiana. Proc Helminthol Soc Wash 52: 44-50.

Klein VLM 1975. Estudo qualitativo e quantitativo da helmintofauna dos peixes Scomberomorus cavalla (Cuvier) e Scomberomorus maculatus (Mitchell) no litoral do Ceará, Brasil. MSc-thesis, Univ. Federal do Rio de Janeiro, Rio de Janeiro, 67 pp.

Linton E 1908. Notes on flesh parasites of marine food fishes. Bull Bureau Fish 28: 1197-1209.

Linton E 1909. Helminth fauna of the Dry Tortugas. I. Cestodes. Carnegie Inst Wash Publ 102: 157-190.

Linton E 1924. Notes on cestode parasites of sharks and skates. Proc US Natl Mus 64: 1-114.

Mehl JAP 1970. Two flesh parasites of barracouta (Teleosti: Gempylidae) from eastern Cook Strait. $N$ Z J mar Freshwat Res 3: 241-247.

Mendes MV 1944. Sobre cestoda de teleósteos marinhos. Bol Fac Fil Cien Letr Univ São Paulo, Zool 43: 173187. 
Obiekezie AI, Anders K, Lick R, Möller H, Palm H 1992. External lesions and flesh parasites in commercial fishes of Nigerian inshore waters. Aquat Living Resour 5: 173-183.

Overstreet RM 1977. Poecilancistrium caryophyllum and other trypanorhynch cestode plerocerci from the musculature of Cynoscion nebulosus and other sciaenid fishes in the Gulf of Mexico. J Parasit 63: 780-789.

Overstreet RM 1978. Trypanorhynch infections in the flesh of sciaenid fishes. Mar Fish Rev 40: 37-38.

Palm H 1995. Untersuchungen zur Systematik von Rüsselbandwürmern (Cestoda: Trypanorhyncha) aus atlantischen Fischen. Ber Inst Meeresk Kiel 275: 238 pp.

Palm H, Möller H, Petersen F 1993. Otobothrium penetrans (Cestoda; Trypanorhyncha) in the flesh of belonid fish from Philippine waters. Int J Parasitol 23: 749-755.

Palm H, Obiekezie AI, Möller H 1994. Trypanorhynch cestodes of commercial inshore fishes of the West African coast. Aquat Living Resour 7: 153-164.

Pereira J 1992. Gradientes latitudinais da prevalência, intensidade e diversidade de parasitos em peixes marinhos. Bol Inf ABRAPOA 2/3: 4-5.

Pereira J, Figueiredo LS, Boeger WAP 1982. Plerocercoides de Trypanorhyncha (Cestoda) em corvinas juvenis, p. 251. Resumos IX Congresso Brasileiro de Zoologia, Porto Alegre, RS.

Petersen F, Palm H, Möller H, Cuzi M 1993. Flesh parasites of fish from central Philippine waters. Dis aquat Org 15: 81-86.

Pissaia Saciloto M 1980. Helmintofauna de Cynoscion leiarchus (Cuvier, 1830) (Pisces, Sciaenidae) de Matinhos, Paraná. MSc-thesis, Univ. Federal do Paraná, Curitiba.

Rego AA 1977. Cestóides parasitos de Carcharinus longimanus (Poey, 1861). Rev Brasil Biol 37: 847852 .

Rego AA 1987. Redescrição de Pterobothrium crassicolle Diesing, 1850 (Cestoda: Trypanorhyncha) e revalidação da espécie. Mem Inst Oswaldo Cruz, 82: 51-53.

Rego AA, Dos Santos JC, Silva PP 1974. Estudos de cestóides de peixes do Brasil. Mem Inst Oswaldo Cruz 72: 187-204.

Reimer LW 1981. Larven der Trypanorhyncha im Fischfleisch. Wiss Z Pädag Hochsch Güstrow 2: 207-211.
Reimer LW 1989. Parasites in marine food fishes. Wiss Z Pädag Hochsch Güstrow 2: 163-166.

Santos CAML, Zogbi EPV 1971. Infestation of fish in Brasil with Tetrarhynchus fragilis larvae, p. 262264. In R Lrezer, Fish Inspection and Quality Control. FAO, Rome.

São Clemente SC 1982. Cestóides importantes na industrialização e comercialização da corvina, Micropogonias furnieri (Desmarest), no Litoral do Estado do Rio de Janeiro. MSc-thesis, Univ. Federal do Rio de Janeiro, Rio de Janeiro, 64 pp.

São Clemente SC 1986a. Plerocercos da ordem Trypanorhyncha, parasitos de corvina Micropogonias furnieri (Desmarest) no litoral do Estado do Rio de Janeiro. Atas Soc Biol Rio de Janeiro 26: 29-36.

São Clemente SC 1986b. Prevalência e intensidade média de infecção de plerocercos de Trypanorhyncha parasitando corvina Micropogonias furnieri (Desmarest) no litoral do Rio de Janeiro. Atas Soc Biol Rio de Janeiro 26: 37-40.

São Clemente SC, Gomes DC 1989a. Dasyrhynchus pacificus Robinson, 1965 (Trypanorhyncha: Dasyrhynchidae) description of the adult form. Mem Inst Oswaldo Cruz 84: 113-116.

São Clemente SC, Gomes DC 1989b. Trypanorhyncha from sharks of southern Brazilian coast: Eutetrarhynchus vooremi sp. n. and two other species parasites of Mustelus (Pisces, Triakidae). Mem Inst Oswaldo Cruz (Suppl. IV) 84: 475-481.

São Clemente SC, Gomes DC 1992. Description of the adult form of Nybelinia (Syngenes) rougetcampanae Dollfus, 1960 and some new data on $N$. (N.) bisulcata (Linton, 1989) (Trypanorhyncha: Tentaculariidae). Mem Inst Oswaldo Cruz (Suppl. I) 87: 251-255.

São Clemente SC, Coelho MRT, Serra-Freire NM 1991. Cestóides Trypanorhyncha parasitos de bagre Netuma sp., pescados no litoral do estado do Rio de Janeiro e utilizados para consumo humano, p. 429. X. Congresso Latino-americano de Parasitologia y Congresso Uruguayo de Parasitologia Resumenes, Intendencia Municipal de Montevideo, MontevideoUruguay.

Schramm M 1991. Grillotia perelica (Cestoda: Trypanorhyncha) plerocercoids in mullet (Pisces: Mugilidae) from estuaries in Transkei, Southern Africa. S Afr J Sci 11: 169-178.

Seyda M 1976. On a case of a mass invasion of cestode Gymnorhynchus (Gymnorhynchus) gigas (Cuvier, 1817) larvae in muscles of Brama raii (Bloch, 1791). Acta Ichthyol Pisc 6: 59-65. 
